\title{
Seasonal Dynamics of Phytoplankton and its Relationship with Environmental Factors of a Chinese Lake
}

\author{
Xiaojiang Chen, Jie Yang*, Hugejiletu, Yuqi Chen, Hong Hou \\ College of Life Sciences Inner Mongolia University, Hohhot, 010021, China
}

Received: 20 January 2015

Accepted: 18 March 2016

\begin{abstract}
What is the relationship with environmental factors of phytoplankton community dynamics in saline lakes? We analyzed a data set of phytoplankton community and environmental parameters in seasonal periods (i.e., summer and autumn) in order to describe seasonal variations within the phytoplankton community and its relationship with environmental variables in Chagan Nur Lake on the Ordos Plateau in China. The lake's phytoplankton species was not abundant, with a mean density of $222.43 \times 10^{4}$ cells $/ \mathrm{L}$ (ranging from $62.35 \times 10^{4}$ cells/ $\mathrm{L}$ in autumn to $382.5 \times 10^{4}$ cells $/ \mathrm{L}$ in summer 2014 ). However, the groups with highest densities were essentially limited to Bacillariophyta, Chlorophyta, and Cyanophyta. There were considerable seasonal variations in phytoplankton composition. Eleven environmental variables were selected to explore the relationship between phytoplankton structure and environmental factors by canonical correspondence analysis (CCA). The results of the CCA applied to the environmental factors indicated that total phosphorus (TP), $\mathrm{pH}$, total ion degrees (Tds), salinity (Sal), and electrical conductivity (Con) significantly influenced the phytoplankton community ( $p<0.01$; Monte Carlo test of first constrained axis).
\end{abstract}

Keywords: phytoplankton function groups, environmental factors, seasonal dynamics, Chagan Nur Lake

\section{Introduction}

Chagan Nur Lake in the southeastern part of China's Ordos Plateau belongs to the north temperate semi-arid continental climate zone [1]. Winters are long and frigid with an average of -27 to $0^{\circ} \mathrm{C}$ in January, and summers are short and cool with an average of $18-28^{\circ} \mathrm{C}$ in July [2]. The Chagan Nur is a typical inland lake, and its ecosystem is not the same as those in humid regions. Factors that regulate seasonal variation in nutrient dynamics and the phytoplankton community in the lake ecosystem could not

*e-mail: cxjmy@126.com use the monitoring rules for lakes in a humid region [3]. However, there have been few reports about the Chagan Nur phytoplankton community.

Phytoplankton research focuses on the eutrophication of lakes because they are sensitive aquatic organisms and their community structure could reflect the eutrophic situation in a short time [4-7]. However, phytoplankton are the water ecological system's important primary producers, and the foundation of the water ecological system structure. Additionally, algae species have a strong ability to adapt to the environment and live in all kinds of waters, especially a few species that can be found under almost any conditions [8]. Therefore, phytoplankton is always used to estimate water quality and eutrophication, 
and as an early warning indicator of the safety of an aquatic ecosystem [9-12]. Planktonic algae were even suited for monitoring very extreme ecosystems where other types of organisms did not adapt [13-14]. In order to research the ecosystem structure of a salinized lake and develop new tools for building restoration strategies in the Chagan Nur, it is necessary to understand the dynamics of phytoplankton community composition and seasonal succession [8]. Nevertheless, at present we have insufficient information on the role of lake's microorganic community to be able to explain and predict the consequences of environmental change.

Although Chagan Nur is a salt lake in a semi-arid area, it has important ecological significance that has rarely been studied. Our study aims to investigate: 1) phytoplankton composition and abundance in Chagan Nur in different seasons, 2) the influence of various environmental factors on phytoplankton growth, and 3) the relationship between environmental factors and phytoplankton functional groups.

\section{Materials and Methods}

\section{Study Area and Sampling Design}

Chagan Nur Lake (39 $18^{\circ}-39^{\circ} 2^{\prime} \mathrm{N}$ and $108^{\circ} 96^{\prime}-108^{\circ} 97^{\prime}$ $\mathrm{E}$ in the Inner Mongolia Autonomous Region of China) is an alkali lake that covers $22 \mathrm{~km}^{2}$. Its water supply is dependent on autumn rain as it has no inflow rivers and no outflow rivers, making it an inland topographically closed lake. As such, it is affected by drought climate, and water levels are reduced annually. The volume of the catchment area was $5.74 \times 10^{6} \mathrm{~m}^{3}$ in 2014 , maximum depth was $1.2 \mathrm{~m}$, water depth range $0.4 \sim 1.2 \mathrm{~m}$ (summer) and $0.3 \sim 1.0 \mathrm{~m}$ (autumn). The lake is subject to atmospheric precipitation recharge, and because of reduced precipitation, gully formation of water flow sometimes dries up so that no water flows into the lake basin. Two water periods in the lake are characterized by temperate continental monsoon climate: a poor-water term (ninemonths - usually from November to June) and a richwater term (the rainy season, commonly from July to September).

Water samples were collected in Chagan Nur during summer and autumn 2014 - twice within a year. In two periods, stations CG-1 to CG-4 were in the water region (Fig. 1).

\section{Analysis of Physico-Chemical Parameters}

Dissolved oxygen (DO), $\mathrm{pH}$ value, water temperature (WT), conductivity (Con), salinity (Sal), and total dissolved solids (TDS) were determined using Hash DREL2800 in-situ instruments. For measuring other parameters, samples were stored in plastic containers for the analysis for chemical variables and chemical oxygen demand (COD). The samples were kept frozen and in the dark before analysis. In the laboratory we measured

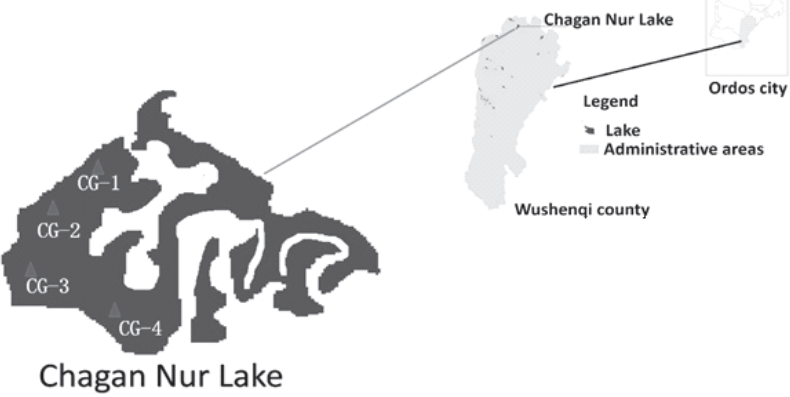

Fig. 1. Location of sampling stations in Chagan Nur Lake.

five chemical variables, including total phosphorus (TP), total nitrogen $(\mathrm{TN}), \mathrm{COD}$, ammonia $\left(\mathrm{NH}_{4}-\mathrm{N}\right)$, and nitrate $\left(\mathrm{NO}_{3}-\mathrm{N}\right)$ using standard methods as described by the Ministry of Environmental Protection of the People's Republic of China [15].

\section{Biological Parameters}

Plankton net hauls ( $0.064 \mathrm{~mm}$ mesh size) were made at the water surface of each sampling site for qualitative analysis. Collections were made at $0.5-\mathrm{m}$ depth using a glass water-sampling device that took a $1 \mathrm{~L}$ water sample from each station and fixed it with $1.5 \%$ acidified Lugol's iodine. Then the supernatant liquid evaporated over $24 \mathrm{~h}$, concentrating the water sample to $30 \mathrm{ml}$. Phytoplankton was counted with a light microscope (Olympus $\mathrm{BH} \times 2$ ) at a magnification of $400 \times$. When some species cells occurred during quantitative analysis they were recorded on a descriptive chart. The whole sample was standing for 30 hours on a laboratory table before we removed supernatant liquid by siphoning. Auxiliary references used in the identification of phytoplankton included $\mathrm{Hu}$ and Wei (2006) [17], Zhou and Chen (2011) [18], www. zaolei.sppchina.com/data.html, the Hydrology Bureau of the Ministry of Water Resources, and the Yangtze River Basin Water Environment Monitoring Center (2012) [19].

\section{Statistical Analysis}

Detrended correspondence analysis (DCA) was applied to estimate the length of gradient range by species data and to judge whether redundance analysis (RDA) or canonical correspondence analysis (CCA) should be used to analyze the relationships between environmental factors and phytoplankton species. Direct gradient analysis methods were used to seek potential or indirect environmental gradient to explain the variations of species [16]. CCA ordination analysis dealt with 11 environment parameters from four sampling regions and phytoplankton function group parameters. A Monte Carlo test with forward selection in CCA analysis was selected to obtain the significance of the correlations between the physicochemical and biological parameters in CANOCO 4.5 [16]. 


\section{Results and Discussion}

The Physicochemical Parameters of Water Quality

Table 1 shows a summary of the measured physicochemical parameters for two seasons. $\mathrm{pH}$ average value of Chagan Nur Lake was 10.1 in the two seasons, which contributed to serious alkalinity.

\section{Seasonal Dynamics of Phytoplankton Communities}

Species richness in the lake was low during the sampling period. A total of 52 algae taxa were identified in the phytoplankton samples. Bacillariophyceae (27), Chlorophyta (14), and Cyanobacteria (8) were the most frequently represented. They were accompanied by two taxa of Euglenophyta and one from Dinophyta. The lake's algal population was not abundant, with a mean density of $222.43 \times 10^{4}$ cells $/ \mathrm{L}$ (ranging from $62.35 \times 10^{4}$ cells $/ \mathrm{L}$ in autumn to $382.5 \times 10^{4}$ cells $/ \mathrm{L}$ in summer 2014.). However, its diversity was essentially limited to Bacillariophyta, Chlorophyta, and Cyanophyta being the groups with highest densities (Fig. 2). The dominant Bacillariophyta species were Navicula bicapitellata, Fragilaria brevistriata, and Navicula exigua. The Chlorophyta community was constituted mainly by Scenedesmus quadricauda, Oocystis lacustris, and Oocystis elliptica. The main Cyanophyta species were Oscillatoria limnetica and Merismopedia tenuissima.

There were considerable seasonal variations in phytoplankton composition (Fig. 2). In this study, Bacillariophyceae was observed in summer, which was higher than autumn, mainly represented by $N$. bicapitellata,

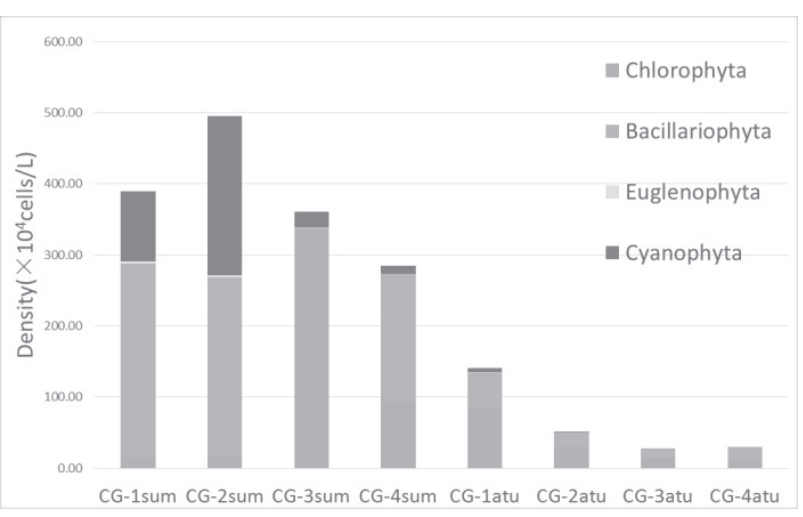

Fig. 2. Variation of total phytoplankton densities. CG-1sum-CG4sum were four sample areas in summer, while CG-1atu-CG4atu were four sample areas in autumn.

F. brevistriata, and $N$. exigua. In the summer research period, Bacillariophyta, Chlorophyta, and Cyanobacteria dominated and respectively represented up to $46.34 \%$, $30 \%$, and $23.25 \%$ of total relative abundance, with the relative abundance of three phylum of algae amounting to $99.59 \%$. In the autumn research period, Chlorophyta and Bacillariophyta dominated and respectively represented up to $54.62 \%$ and $42.44 \%$, respectively; the relative abundance of Cyanophyta algae was $2.73 \%$; and the relative abundance of three phylum of algae $r$ epresented up to $99.79 \%$ of total relative abundance. In the summer and autumn phytoplankton average density was $222.43 \times 10^{4}$ cells/ L. In the lake's four sampling areas, the density of phytoplankton sequence was: in the summer CG-2sum > CG-1 sum > CG-3sum > CG-4sum, CG-1atu $>$ CG-2atu $>$ CG-4atu $>$ CG-3atu.

Table 1. Chagan Nur Lake dynamic seasonal environmental factors.

\begin{tabular}{|c|c|c|c|c|c|c|c|c|}
\hline & \multicolumn{4}{|c|}{ Summer } & \multicolumn{4}{c|}{ Autumn } \\
\hline & CG-1sum & CG-2sum & CG-3sum & CG-4sum & CG-1atu & CG-2atu & CG-3atu & CG-4atu \\
\hline $\mathrm{NH}_{4}-\mathrm{N}$ & 6.29 & 1.19 & 2.80 & 4.70 & 0.925 & 1.256 & 0.694 & 0.575 \\
\hline $\mathrm{NO}_{3}$-N & 1.43 & 1.41 & 0.78 & 1.39 & 0.81 & 1.53 & 0.39 & 0.33 \\
\hline $\mathrm{TN}$ & 16.24 & 3.37 & 4.02 & 6.63 & 3.8 & 3.5 & 3.6 & 2.7 \\
\hline $\mathrm{TP}$ & 0.12 & 0.53 & 0.34 & 1.36 & 0.120 & 0.135 & 0.170 & 0.177 \\
\hline $\mathrm{COD}$ & 351.81 & 528.48 & 233.26 & 358.69 & 93 & 76 & 174 & 89 \\
\hline $\mathrm{WT}$ & 30.5 & 29.4 & 28.4 & 29.2 & 10.8 & 10.6 & 11.4 & 11.6 \\
\hline $\mathrm{pH}$ & 10.89 & 9.9 & 8.75 & 10.26 & 10.78 & 10.29 & 10.13 & 9.52 \\
\hline $\mathrm{Sal}$ & 4 & 5.6 & 5.6 & 4.4 & 4.6 & 4.9 & 5.4 & 5.4 \\
\hline $\mathrm{con}$ & 7.23 & 9.95 & 10.04 & 8.1 & 11.33 & 11.12 & 9.66 & 9.62 \\
\hline $\mathrm{Tds}$ & 383 & 543 & 545 & 432 & 669 & 655 & 525 & 523 \\
\hline DO & 6.67 & 6.25 & 6.68 & 6.4 & 2.42 & 2.38 & 2.2 & 1.9 \\
\hline
\end{tabular}

Notes: WT (unit: ${ }^{\circ} \mathrm{C}$ ), $\mathrm{CON}$ (unit: $\mathrm{mS} / \mathrm{cm}$ ), DO, $\mathrm{NH}_{4}-\mathrm{N}, \mathrm{COD}, \mathrm{TN}, \mathrm{TP}$, and Tds all units: $\mathrm{mg} / \mathrm{L} \sim \mathrm{CG}-1$ sum $\sim \mathrm{CG}-4$ sum: four samples area in summer, CG-1atu CG-4atu: four samples area in autumn. 
Table 2. The relative abundance of phytoplankton functional groups in Chagan Nur Lake (\%).

\begin{tabular}{|l|c|c|c|c|c|c|c|c|}
\hline & J & X1 & Tc & W1 & F & D & Wo & P \\
\hline CG-1sum & 1.1 & 0.5 & 31 & 0.4 & & & & 1.2 \\
\hline CG-2sum & 1.3 & 0.4 & 29.3 & 0.5 & & & & \\
\hline CG-3sum & 40.3 & 4.2 & 1.6 & & 2.8 & & & \\
\hline CG-4sum & & 15.1 & 2 & & 7.4 & 2 & 1.1 \\
\hline CG-1atu & 5.9 & 10.3 & & 0.4 & 12.5 & & 4.4 & 1.1 \\
\hline CG-2atu & & 0.5 & & & 16.5 & & 1 & 1.2 \\
\hline CG-3atu & 8 & 0.5 & 0.5 & & 4 & 26 & & 10.5 \\
\hline CG-4atu & & 7 & & & 8.8 & & \\
\hline
\end{tabular}

Note: Relative abundance is greater than $5 \%$ as representative functional groups; CG-1 sum $\sim$ CG-4sum were sampling areas in summer and CG-1atu CG-4atu were sampling areas in autumn.

\section{Seasonal Succession of Phytoplankton Functional Groups}

Phytoplankton functional group divisions are based on the ecological characteristics of phytoplankton individuals, so in order to explain the ecological environment change and the relationship between phytoplankton community succession, we must fully reveal the biological adaptability to the environment in order to better explain the process of ecosystem structure and function. In the traditional classification methods of phytoplankton, Lin Nai taxonomy, and the molecular identification method, based on Reynold (2002) and Padisak (2009), the function of supplement classification rules [20-21] uses the concept of phytoplankton functional groups.

Chagan Nur phytoplankton species are divided into eight functional groups: $\mathrm{X} 1 / \mathrm{F} / \mathrm{P} / \mathrm{D} / \mathrm{W} 1 / \mathrm{Wo} / \mathrm{J} / \mathrm{Tc}$. Among them are the summer $(\mathrm{X} 1 / \mathrm{Tc} / \mathrm{J} / \mathrm{P} / \mathrm{W} 1 / \mathrm{F} / \mathrm{D})$ and its representative functional groups for $(\mathrm{X} 1 / \mathrm{Tc} / \mathrm{J} / \mathrm{F})$ and autumn (X1/Tc/J/P/W1/F/D/Wo) and its representative functional groups for $(\mathrm{J} / \mathrm{X} 1 / \mathrm{F} / \mathrm{D})$. The seasonal dynamics of representative functional groups are as follows: $(\mathrm{X} 1 / \mathrm{Tc} /$ $\mathrm{J} / \mathrm{F})$ in summer to $(\mathrm{J} / \mathrm{X} 1 / \mathrm{F} / \mathrm{D})$ in autumn. The temporal and spatial distribution of phytoplankton function are shown in Table 2. The relative abundance of phytoplankton functional groups was greater than $5 \%$ as representative of functional groups based on Reynold and Padisak, according to the rules of analysis for Chagan Nur Lake functional groups: $\mathrm{J} / \mathrm{P} / \mathrm{S} 2 / \mathrm{C} / \mathrm{Tc} / \mathrm{X} 1 / \mathrm{Xph}$.

\section{Relationships between Physical-Chemical Parameters and Phytoplankton Functional Groups}

Based on the detrended correspondence analysis (DCA) of the representative phytoplankton functional groups, the maximum gradient in four axis length values was 3.169, between $3-4$, so the analysis of a single model was suitable for CCA. The DCA ordination of the eight samplings showed that the first axis eigenvalue $(0.841)$ was larger than the second axis (0.524). The cumulative percentage of species environment relationship was $75.7 \%$ (Table 3).

From Fig. 3 to analysis can explain the state of the environment whose factors were $\mathrm{pH}$, Con, total ion degrees (Tds), nitrate nitrogen $\left(\mathrm{NO}_{3}-\mathrm{N}\right)$, water temperature (WT), DO, COD, and Sal. Among them, pH, total phosphorus (TP) into a significantly negative correlation with the second axis $(p<0.01)$, it showed $\mathrm{pH}$, TP, was the limiting factors of phytoplankton functional groups of Chagan Nur Lake. WT and DO were positively correlated with the first axis and the second axis, but the correlation was relatively low. Con and Tds were a significant negative correlation with the first axis, showing that they were the limiting factors of the environmental gradient. $\mathrm{NO}_{3}-\mathrm{N}, \mathrm{COD}, \mathrm{TN}$, and $\mathrm{NH}_{4}-\mathrm{N}$ with the first axis were positively correlated, indicating that these factors promote the development of positive environmental gradient. Sal has a positive correlation with the first axis, but the correlation was not significant. From Fig. 3 we see that in the three summer and autumn sampling areas environmental factors were differently significant, but the CG-4's environmental factors were similar in the two seasons.

Fig. 3 shows the influence of environmental variables on the distribution of phytoplankton functional groups in the study stations, as determined by $\mathrm{CCA} . \mathrm{NH}_{4}-\mathrm{N}, \mathrm{NO}_{3}-\mathrm{N}$, $\mathrm{TN}$, and COD were closely related to Axis 1 , indicating

Table 3. Eigenvalues for CCA axis and species-environment correlation.

\begin{tabular}{|c|c|c|c|c|}
\hline Axes & 1 & 2 & 3 & 4 \\
\hline Eigenvalues & 0.841 & 0.524 & 0.442 & 0.169 \\
\hline $\begin{array}{c}\text { Species-environment } \\
\text { correlations }\end{array}$ & 1 & 1 & 1 & 1 \\
\hline $\begin{array}{c}\text { Cumulative percentage } \\
\text { variance of species data }\end{array}$ & 41.1 & 66.8 & 88.4 & 96.7 \\
\hline $\begin{array}{c}\text { Species-environment } \\
\text { relation }\end{array}$ & 41.1 & 66.8 & 88.4 & 96.7 \\
\hline
\end{tabular}




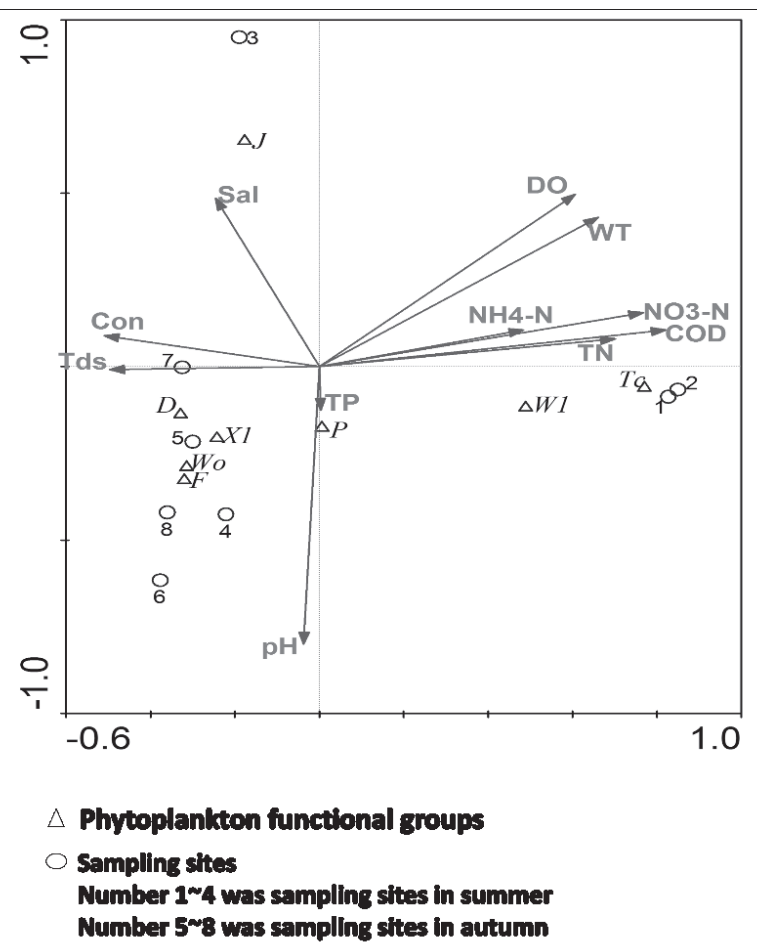

Fig. 3. Ordination plots of phytoplankton functional classification in respect to environmental CCA variables.

an obvious organic gradient along the first axis, Con and Tds negatively correlated with Axis 1 , and $\mathrm{pH}$ and $\mathrm{TP}$ negatively correlated with Axis 2.

\section{Seasonal Succession Dynamics of Phytoplankton Functional Groups}

Chagan Nur phytoplankton functional groups that adapted to environmental characteristics were mainly:

- S2 (Spirulina), suitable for growth in warm, shallow, high alkalinity water; J functional group (Scenedesmus, Pediastrum), which adapts to a more mixed shallow water environment.

- W1 (Euglena sp.), J, P (Melosira granulata, Meosira granulata var. angustissima), X1 (Chlorella pyrenoidosa, Chlorella ellipsoidea), and Tc (Oscillatoria ornata, Oscillatoria limnetica) functional groups have strong tolerance to adapt to high-salinity water, shallow water habitats, and are distributed through a wide range of the habitat.

- 'D' group ( Synedra acus) was suitable for cloudy shallow water environments.

- 'F' group (Oocystis lacustris) could tolerate highsalinity environments.

The different rates of the phytoplankton functional groups in two seasons were compared, with results showing less 'Wo' group (Oscillatoria chlorine, Phacus abruptus korschikow) in summer than in autumn with a difference of $12.5 \%$. Variation of the representative functional groups from the summer to autumn were $(\mathrm{X} 1 / \mathrm{Tc} / \mathrm{J} / \mathrm{F}) \rightarrow(\mathrm{J} /$ $\mathrm{X} 1 / \mathrm{F} / \mathrm{D})$. In summer and autumn groups $\mathrm{X} 1 / \mathrm{J} / \mathrm{F}$ have the same function. The representative functional groups in summer were compared with autumn (the different functional groups were $\mathrm{Tc}$ and $\mathrm{D}$ ) and the difference was $40 \%$, showing that representative functional groups could reveal the dynamic characteristics of the seasonal variations within the phytoplankton community [22].

The Interaction between Phytoplankton Functional Groups with Environmental Factors

Chagan Nur Lake has long been used for development of mineral resources, resulting in reduced complexity of the lake ecosystem, weak self-organizational ability, and ecological fragility. The food chains in water were mainly composed of phytoplankton, zooplankton, and insect larvae. Due to the water $\mathrm{pH}$ value being high, the majority of species survival was restricted. So although water nutrients, light, and dynamic characteristics are suitable for the growth of phytoplankton and predation pressure and competitive pressure are small due to the lack of fish and aquatic plants in water, only the water's environmental, physical, and chemical factors affected the succession of phytoplankton functional groups. CCA analysis was applied to the length of the gradient of environmental factors in two axes. The main driving factors of seasonal variation dynamics of phytoplankton functional groups were $\mathrm{pH}, \mathrm{Sal}, \mathrm{WT}, \mathrm{CON}, \mathrm{Tds}, \mathrm{DO}, \mathrm{NO}_{3}-\mathrm{N}, \mathrm{TN}$, and COD, and the correlation with the first two ordination axes showed that the most significant factors were $\mathrm{pH}, \mathrm{CON}$, Tds, $\mathrm{NO}_{3}-\mathrm{N}, \mathrm{TN}, \mathrm{COD}, \mathrm{NH}_{4}-\mathrm{N}$, and TP, among which $\mathrm{pH}$ and TP with axis 2 showed extremely significant negative correlation, and Tds in the first axis showed a significant negative correlation.

The Chagan Nur Lake was a saline lake, so the factors can reflect the environment characteristics which were the electrical conductivity (Con), total ion degree (Tds) and $\mathrm{pH}$, so in this environment, the main environmental factors affecting the ecological system structure that were also the electrical conductivity (Con), total ion degrees(Tds) and $\mathrm{pH}$. The electrical conductivity was an important parameter for monitoring water environmental quality, had an important influence on the phytoplankton community composition, variation of water electrical conductivity would lead to phytoplankton diversity being changed [23], its proportional to nutrient contents[24]. In Chagan Nur Lake water, with the value of electrical conductivity increasing that $\mathrm{D} / \mathrm{X} 1 / \mathrm{Wo} / \mathrm{F}$ function groups' species and relative abundance were increase, from CCA analysis shows a positive correlation between the $\mathrm{D} / \mathrm{X} 1 /$ $\mathrm{Wo} / \mathrm{F}$ function groups with electrical conductivity. The $\mathrm{pH}$ value was the main limiting factor for biological growth [25-27]. and the maximum $\mathrm{pH}$ value of Chagan Nur was 10.78 during ecological investigation, it is main factor affecting for the phytoplankton community structure, from CCA analysis, showed a extremely significant negative correlation with the second axis $(p<0.01)$.

Our comparative Chagan Nur Lake and in prairie saline lakes of the northern Great Plains (U.S.A.) did not 
show similar in major seasonal changes in phytoplankton communities. Seasonal patterns of phytoplankton phyla changes in prairie saline lakes of the northern Great Plains (U.S.A.) were similar to those of freshwater systems [28], which these lakes were dominated by Cyanobacteria in the summer, with a shift to Bacillariophyta-dominated communities in the autumn. However, in Chagan Nur Lake were Bacillariophyta-dominated communities in the summer shift to Cyanobacteria-dominated in the autumn. This is particularly interesting that Chagan Nur Lake like as freshwater lakes (such as the Haizi reservoir in Beijing [29]) were generally P limited, whereas in prairie saline lakes of the northern Great Plains (U.S.A.) were N limited. These differences in nutrient limitation patterns in Chagan Nur Lake versus saline lakes of the northern Great Plains (U.S.A.) lead to the phytoplankton communities appear to be relatively different on a phylum level in the season, and nutrient limitation patterns were significantly associated with climate change[30].

\section{Conclusions}

Seasonal changes in phytoplankton communities of Chagan Nur Lake were different with those seen in many freshwater systems, such as the density and functional goups of phytoplankton of Chagan Nur Lake were lower than the freshwater lake, differences in nutrient limitation.Major drivers of phytoplankton varied by the environmental factors indicated that total phosphorus (TP), $\mathrm{pH}$, the total ion degrees (Tds), salinity (Sal) and electrical conductivity (Con). Future work is needed to make Deep Investigation of seasonal succession patterns of phytoplankton communities in these saline lake systems. Information on seasonal changes in phytoplankton community structure and distribution patterns in saline lakes in Ordos plateau will allow us to understand mechanisms behind changes in important ecosystem processes such as primary production, and explore how these valuable plateau saline lake systems may respond to future climate changes.

\section{Acknowledgements}

This was supported the National Science and Technology Support Project (2011BAC07B00). We are grateful for laboratory analysis to Inner Mongolia University Water Resource and Environment Institute. The assistance of Inner Monogolia Management center of maowusu sandy land with the field work is also acknowledged.

\section{References}

1. WU X.X., ZOU X.Y. Analysis of landscape pattern change and its driving factors basedon 3S technology: a case study in Uxin Banner of Inner Mongolia. Journal of Desert Research. 30 (4), 763, 2010 [in Chinese].
2. JIN Y., MENG J.J., HUANG J. Grassland Ecological Vulnerability Assessment of Mu Us Desert in Recent 50 Years: A Case Study of Wushen Banner. Acta Scientiarum Naturalium Universitatis Pekinensis. 47 (5), 909, 2010 [in Chinese].

3. WANG Y.J., SUN Z.D. Lakes in the Arid Areas in China. Arid Zone Research. 24 (4), 422, 2007 [in Chinese].

4. MA S., WANG C.L., ZHANG Y.J., JANG X.Y., RENG S.X., LI X.Y., MA J.M. Influences of nitrogen and phosphorus concentration on interactions among chlorelia vugaris, daphnia magna and ceratophyllum demersum. Acta Hydrobiologica Sinica. 36 (1), 66, 2012 [in Chinese].

5. LIU X.H., FENG L.Q., ZhANG Y.L. Effects of hydrodynamic process on bio-optical properties in Algal-Dominated lake region of Shallow Lake.Environment Science 33 (2), 412, 2012 [in Chinese].

6. PAN H., YANG Y., TAO R. Simulation of phytoplankton community succession mechanism of water improvement. Acta Scientiae Circumstantiae 33 (12), 3309, 2013 [in Chinese].

7. JING M., LI J.Y., LIU M.Y. Canonical Correspondence Analysis Between Phytoplankton Community and Environmental Factors in Yangcheng Lake. Environmental Science and Management. 39 (11), 145, 2014 [in Chinese].

8. MA Y., LI G.B., LI J. Seasonal succession of phytoplankton community and its relationship with environmental factors of North Temperate Zone water of the Zhalong wetland, in China. Ecotoxicology, 23 (2), 618, 2014.

9. GAO Y., SU Y.X., QI S.C. Phytoplankton and evaluation of water quality in Yi River watershed. J. Lake Sci. 20 (4), 544, 2008 [in Chinese].

10. WANG Y., LIU L.S., SHU J.M. Community structure of phytoplankton and the water quality assessment in Lake Baiyang-dian. J. Lake Sci, 23 (4), 575, 2011.

11. CHEN X.J., GAO Q., DU G.S., MA W.L., WANG X.L. Analysis on the eutrophication and water quality of Honglingjin Lake in Beijing. Environmental Pollution \& Control. 33 (5), 36, 2011 [in Chinese].

12. LIU J.J., QIAN R.B., WANG B., XU X. A Study on the Plankton Features and Water Quality assessment of Tashan Reservoir in Spring Season. Pollution Control Technology. 26 (5), 14, 2013 [in Chinese].

13. TAYLOR J.C., PRYGIEL J., VOSLOO A., REY P.A., RENSBURG 1. Can diatom-based pollution indices be used for biomonitoring in South Africa? A case study of the Crocodile West and Marico water management area. Hydrobiologia. 592 (1), 455, 2007.

14. GAO J., ZHOU M., MIN T.T., LIU Z.W. Response of the phytoplankton functional groups to ecological restoration in Huizhou Lake. Ecological Science. 32 (5), 540, 2013 [in Chinese].

15. MINISTRY OF ENVIRONMENTAL PROTECTION OF THE PEOPLE'S REPUBLIC OF CHINA. Environmental quality standards for surface water (GB3838-2002), China Environmental Science Press: Beijing, 2002 [in Chinese].

16. ZHANG J.T. Quantitative ecology (The second edition), Science press: Beijing, 2011 [in Chinese].

17. HU H.J., WEI Y.X. The freshwater algae of China. Science press: Beijing, 2006 [in Chinese].

18. ZHOU F.X., CHEN J.H. Freshwater micro biological map. Chemical industry press:Beijing, 2011 [in Chinese].

19. THE HYDROLOGY BUREAU OF MINISTRY OF WATER RESOURCES OF CHINA AND THE YANGTZE RIVER ENVIRONMENT MONITORING CENTER.China's inland waters common algae map, The Yangtze river press:Wuhan, 2012 [in Chinese]. 
20. REYNOLDS C.S., HUSZAR V., KRUK C., NASELLIFLORES L., MELO S.Towards a functional classification of the freshwater phytoplankton. Journal of Plankton Research, 24 (5), 417, 2002.

21. PADISÁK J., CROSSETTI L.O., NASELLI-FLORES L. Use and misuse in the application of the phytoplankton functional classification: a critical review with updates. Hydrobiologia, 621 (1), 1, 2009.

22. LU X.X., LIU Y., FAN Y.W. Relationships between environmental variables and seasonal succession inphytoplankton functional groups in the Hulan River Wetland. Acta Ecologica Sinica, 34 (5), 1264, 2014.

23. LI D.L., ZANG T., XIAO T.Y. Phytoplankton's community structure and its relationships with environmental factors in an aquaculture lake. Datong Lake of China, Chinese Journal of Applied Ecology, 23 (8), 2107,2012 [in Chinese].

24. LIU X.R. Research Progress on Diatom Based on Effects of Environment.Journal of Anhui Agri. Sci. 38 (6), 3092, 3104, 2010 [in Chinese].

25. LIU H.Y., XU Y.L. Preliminary Observations of Algae
Growth and Lake Eutrophication In Jingbo Lake.Acta Ecological Sinic,16 (2), 195, 1996 [in Chinese].

26. WANG W.L., ZHOU R.Y., CHEN Q.L. Characteristics of water quality in the Danjiangkou Reservoir. Transactions of Oceanology and Limnology. 2008 (2), 123, 2008.

27. XU H. Study of Phytoplankton Ecology and Limiting Factors to Eutrophication. (D). Nanjing agricultural university: Nanjing, 2008 [in Chinese].

28. SALM C.R., SAROS J.E., MARTIN C.S., ERICKSON J.M. Patterns of seasonal phytoplankton distribution in prairie saline lakes of the northern Great Plains (U.S.A.). Saline Systems, 5 (1), 1, 2009.

29. Chen X.J.,YANG J.,DU G.S.,LIU B. Relationships between environmental variables and seasonal succession in phytoplankton functional groups in the Haizi reservoir. Water Resources Protection, 31 (6), 122, 2015 [in Chinese].

30. LIU S.W. Physiological responses of marine Synechococcus sp. Restrictions on iron. (D). Central China Normal University Wuhan, 2012 [in Chinese]. 